\title{
Confissões da carne: uma experiência clínica de atendimento psicoterapêutico a transexuais
}

\author{
Marcos de Jesus Oliveira \\ Orientador: Deis Elucy Siqueira \\ Tese de Doutorado \\ Data da defesa: 14.02.2013
}

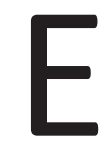

ste estudo analisa as formas de poder/saber que regulam a prática psicoterápica destinada a pessoas transexuais requerentes da cirurgia de transgenitalização em um hospital universitário brasileiro localizado em um grande centro urbano. Trata-se, para colocar em termos simples, de entender como o diagnóstico de disforia de gênero é construído nas e pelas interações terapêuticas destinas ao público investigado. Por meio de observação participante em sessões terapêuticas, foi reconstituída a "microfísica do poder" da clínica, seus regimes de subjetivação. Esses regimes funcionam como um dispositivo cujas forças atuam no sentido de conformar as subjetividades ali produzidas a certos ideais regulatórios, disciplinares e biopolíticos, característicos da modernidade ocidental. Entrevistas semiestruturadas aplicadas às que se submeteram a atendimento psicoterápico como parte do programa de acesso à cirurgia de transgenitalização complementam a estratégia teórico-metodológica descrita, de modo a viabilizar o objetivo anteriormente mencionado, bem como dar a ver as negociações e subversões da norma como possibilidades de resistência no interior dos regimes hegemônicos de subjetivação do contexto institucional investigado. O aprofundamento do segundo objetivo segue informado pela Sociologia da diferença infinitesimal, colocando em destaque o processo complexo e multifacetado de formação das identidades de gênero a partir dos elementos múltiplos e fluídos dentro das posições identitárias. 0 debate sobre a formação das identidades ocorre ainda no âmbito da proposta teórica da Sociologia simétrica, a partir da qual será sugerido que as identidades são indissociáveis da relação entre o mundo humano e não humano.

Palavras-chave: Transexualidade; Corpo; Clínica; Gênero. 